\title{
Summer Cover Crops and Lettuce Planting Time Influence Weed Population, Soil Nitrogen Concentration, and Lettuce Yields
}

\author{
Raymond Kruse and Ajay Nair ${ }^{1}$
}

AdDitional INDEX wORDs. allelopathy, biomass, $\mathrm{C}: \mathrm{N}$ ratio, cowpea, sorghum-sudangrass, sustainable vegetable production, weed suppression

Summary. Cover crops can be used as a sustainable weed management tool in crop production systems. Cover crops have the ability to suppress weeds, reduce soil erosion, increase soil organic matter, and improve soil physical, chemical, and biological properties. In the north-central region of the United States, including Iowa, much cover crop research has been conducted in row crop systems, mainly with corn (Zea mays) and soybean (Glycine max) where cover crops are planted at the end of the growing season in September or October. There is little information available on the use of cover crops in vegetable cropping systems, particularly on the use of summer cover crops for fall vegetable production. The choice of the cover crop will significantly impact the entire fall vegetable production enterprise. Vegetable growers need information to identify the right cover crop for a particular slot in the cropping system and to understand how cover crops would affect weed suppression, soil properties, and successive vegetable crop yield. The time interval between cover crop termination and vegetable planting critically affects the growth and successive yield of the vegetable crop. This study investigated how shortduration summer cover crops impact weed suppression, soil properties, and 'Adriana' lettuce (Lactuca sativa) yield. The study also examined appropriate planting times of lettuce transplants after soil incorporation of cover crops. The experimental design was a randomized complete block split-plot design with four replications. Whole plots consisted of cover crop treatments: 'Mancan' buckwheat (Fagopyrum esculentum), 'Iron \& Clay' cowpea/southernpea (Vigna unguiculata), black oats (Avena strigosa), 'Grazex II' sorghum-sudangrass (Sorghum bicolor ssp. drummondii), and a control (no-cover crop) where weeds were left to grow unchecked. The subplot treatment consisted of two lettuce transplanting times: planted immediately or 8 days after cover crop soil incorporation. Fall-planted butterhead lettuce was used. Data were collected on cover crop biomass, weed biomass, soil nutrient concentration, lettuce growth, and yield. All cover crops significantly reduced weed biomass during the fallow period as compared with the control treatment. Highest degree of weed suppression $(90 \%$ as compared with the no-cover crop control treatment) was provided by buckwheat. Southernpea, a legume, increased soil nitrogen $(\mathrm{N})$ concentration and contributed to higher lettuce yield and improved quality. Southernpea also enhanced lettuce growth and led to an earlier harvest than other treatments. Sorghum-sudangrass showed evidence of detrimental effects to the marketable lettuce crop. This was not due to $\mathrm{N}$ immobilization but presumably due to alleopathic properties. There is no clear pattern within any cover crop treatment that lettuce planting time following cover crop termination affects plant growth; however, planting early or soon after cover crop incorporation ensures more growing degree days and daylight, thus leading to timely harvest of a higher quality product. This study demonstrates that cover crops can successfully be integrated into vegetable cropping systems; however, cover crop selection is critical.

$\mathrm{D}$ epending on their production systems and markets, vegetable growers can grow crops that either occupy an entire growing season or a few months of the growing

Department of Horticulture, Iowa State University, 106 Horticulture Hall, Ames, IA 50011

This paper is part of a thesis by the first author for a M.S. degree.

This work was supported by North-Central SARE PDP grant no. ENC12-132.

We thank the graduate and undergraduate students and staff at the Horticulture Research Station, IA State University for their assistance with field work.

${ }^{1}$ Corresponding author. E-mail: nairajay@iastate.edu. season. In a late-planted fall vegetable production system where no other cash crop occupies the soil for the preceding part of the season, weeds can grow and contribute large amounts of seeds to the soil weed seed bank (Kumar et al., 2009). During this summer fallow season, many midwestern U.S. vegetable growers manage weeds by means of tillage or herbicides. Although effective, herbicides and excessive tillage lead to environmental issues such as herbicide-resistant weeds (Chatham et al., 2015) and reduced soil organic matter (Reicosky et al., 1995). Cover crops are an alternative to tillage and herbicides and offer additional benefits to the soil and environment while also increasing or maintaining vegetable yield (Kumar et al., 2009). Studies have reported successful weed suppression using cover crops (Bugg and Dutcher, 1989; Kumar et al., 2009) while also improving yield of the successive vegetable crop (Sainju et al., 2002). Observed mechanisms of weed suppression reported are weed seed reduction (Kumar et al., 2009), allelopathy (Rueda-Ayala et al., 2015), and reduction of weed seed germination following cover crop soil incorporation (Kumar et al., 2009).

Not only can cover crops be a suitable alternative to herbicides and tillage but also can provide other environmental benefits. Soil organic matter is one aspect that cover crops can influence in a positive way (Mukherjee and Lal, 2015). Ding et al. (2006) reported increased soil organic matter in soils with cover crops compared with a no-cover crop (control). Cover crops also benefit pollinators (Clark, 2007), improve soil fertility (Teasdale, 1996), and increase soil microbial biomass (Buyer et al., 2010). Corak et al. (1991) and De Baets et al. (2011) reported reduction in soil erosion especially with fibrous rooted cover crops such as common oats (Avena sativa).

\begin{tabular}{llll}
\hline $\begin{array}{l}\text { Units } \\
\begin{array}{l}\text { To convert U.S. to SI, } \\
\text { multiply by }\end{array}\end{array}$ & U.S. unit & SI unit & $\begin{array}{l}\text { To convert SI to U.S., } \\
\text { multiply by }\end{array}$ \\
\hline 0.4047 & acre $(\mathrm{s})$ & $\mathrm{ha}$ & $2.471 \mathrm{l}$ \\
73.0778 & $\mathrm{fl} \mathrm{oz} / \mathrm{acre}$ & $\mathrm{mL} \cdot \mathrm{ha}^{-1}$ & 0.0137 \\
0.3048 & $\mathrm{ft}$ & $\mathrm{m}$ & 3.2808 \\
0.0929 & $\mathrm{ft}^{2}$ & $\mathrm{~m}^{2}$ & 10.7639 \\
0.1242 & gal/100 ft & $\mathrm{L} \cdot \mathrm{m}^{-1}$ & 8.0520 \\
2.54 & inch $(\mathrm{es})$ & $\mathrm{cm}$ & 0.3937 \\
25.4 & inch $(\mathrm{es})$ & $\mathrm{mm}$ & 0.0394 \\
1.1209 & lb/acre & $\mathrm{kg} \cdot \mathrm{ha}^{-1}$ & 0.8922 \\
70.0532 & $\mathrm{oz} / \mathrm{acre}$ & $\mathrm{g} \cdot \mathrm{ha}^{-1}$ & 0.0143 \\
1 & $\mathrm{ppm}$ & $\mathrm{mg} \cdot \mathrm{kg}^{-1}$ & 1 \\
$\left({ }^{\circ} \mathrm{F}-32\right) \div 1.8$ & ${ }^{\circ} \mathrm{F}$ & ${ }^{\circ} \mathrm{C}$ & $\left({ }^{\circ} \mathrm{C} \times 1.8\right)+32$
\end{tabular}


Vegetable growers in the midwestern United States know the importance and relevance of cover crops in their cropping systems but are hesitant to use cover crops, especially in the summer. The variable climate and narrow seasonal window for growing vegetables in Iowa demands maximum use of the growing period to grow cash crops, thus innovative strategies have to be developed for integration of cover crops and cover crop mixtures in vegetable cropping systems. Often there is a 4 to 6 week summer fallow between spring/summer harvested and fall planted vegetable crops. This period could benefit from a cover crop but growers need cover crops that would grow in that short time and provide benefits, but at the same time are easy to terminate and do not harm the successive vegetable crop. Few studies have experimented with summer cover crops and their influence on vegetable crop production (Creamer and Baldwin, 2000; Wang et al., 2008a). More information and research is needed on cover crop type, the biomass they generate, and the effects they have on soil properties and succeeding vegetable crops. Additionally, appropriate planting time, after cover crop soil incorporation, needs to be evaluated, since negative impacts of cover crops on succeeding vegetables have been reported (Ackroyd and Ngouajio, 2011).

The primary objective of this study was to identify appropriate summer cover crops and investigate their effects on fall lettuce production in the midwestern United States. The study also evaluated the interval between cover crop incorporation and lettuce planting to determine the right planting time. This information can help growers identify a suitable cover crop that can provide weed suppression during fallow and improve soil properties without detrimentally affecting lettuce growth and yield.

\section{Materials and methods}

EXPERIMENT sITE. This experiment was conducted at the Iowa State University Horticulture Research Station, Ames, during the 2013 and 2014 growing seasons. The experiment was carried out on the same plot for both years. Before the commencement of this study, the field was used for sweetpotato production. The soil type was a Clarion series, which is a fine-loamy, Typic Hapludoll with a slope of $2 \%$ to $6 \%$. Predominant weeds in this soil include common lambsquarter (Chenopodium album), green foxtail (Setaria viridis), greenflower pepper weed (Lepidium densiflorum), pennsylvania smartweed (Polygonum pensylvanicum), prickly lettuce (Lactuca serriola), shepherd's purse (Capsella bursa-pastoris), and yellow foxtail (Setaria pumila).

WeAther. Rainfall in 2013 was much below the 30 -year average for the entire growing season as seen in Fig. 1A (Iowa State University, 2015). Rainfall in 2014 was above the 30 -year average for the entire growing season except for July and November. Temperatures were higher in 2013 than in 2014 for the span of the experiment (Fig. 1B). The growing degree days, calculated with a base temperature of $50{ }^{\circ} \mathrm{F}$, were very similar in both years (Fig. 1C)

Experimental Design. This experiment had a split-plot randomized complete block design with four replications. Individual plots were $612 \mathrm{ft}^{2}$ ( $25.5 \mathrm{ft}$ long by $24 \mathrm{ft}$ wide). Whole plot treatments were 'Mancan' buckwheat, 'Iron \& Clay' southernpea, black oats, 'Grazex II' sorghumsudangrass, or a no-cover crop (control). The subplot treatment was planting time of lettuce after the soil incorporation of cover crop (immediately or $8 \mathrm{~d}$ later). Throughout this paper when discussing a specific combination of cover crop and planting time, the following abbreviation will be used: "buckwheat-early" where "buckwheat" denotes the cover crop and "early" denotes the immediate planting time of lettuce. Likewise, "buckwheat-late" denotes "buckwheat" cover crop and "late" denotes lettuce planted 8 d after cover crop soil incorporation.

Cover crop establishment AND GROWTH. Cover crops were seeded on 2 June 2013 and 12 June 2014. Sorghum-sudangrass seeding was delayed by $4 \mathrm{~d}$ in 2014 due to delayed seed shipment. Before cover crop seeding, the plot was tilled using a rototiller (550; John Deere, Moline, IL) to a depth of 4 to 6 inches. A 42 -inch variable rate drop spreader (Gandy; Anertec \& Gandy Co., Owatonna, MN) was used to seed the cover crop at predetermined calibrated settings. Southernpea seeds were inoculated with appropriate Rhizobium strain before seeding. The seeding rates of cover crops consisted of 50, 85,
60 , and $50 \mathrm{lb} /$ acre of buckwheat, southernpea, black oats, and sorghumsudangrass, respectively. An additional shallow pass with the rototiller was made to incorporate the cover crop seed to a depth of 2 inches. Aboveground cover crop biomass was collected on 4 Aug. 2014 before cover crop soil incorporation. Cover crop biomass was collected using two $0.25-\mathrm{m}^{2}$ quadrats from each cover crop plot. Weed biomass (root + shoot) was also pulled from the same quadrat. Weeds were separated into broadleaf and grass weeds. Cover crop and weed biomass were dried in an oven for $3 \mathrm{~d}$ at $67^{\circ} \mathrm{C}$ and then weighed. Cover crops in the field were terminated using a flail mower (ORC 10; Rhino, Gibson City, IL) on 6 Aug. 2013 and 5 Aug. 2014 followed by rototilling to a depth of 8-10 inches.

Transplant production and FIELD PLANTING. To account for two planting times in the field, two batches of 'Adriana' lettuce seed were sown, $8 \mathrm{~d}$ apart. Pelleted lettuce seeds were sown in 98-cell trays using soilless growing medium (LCl; Sun Gro Horticulture Canada, Seba Beach, AB, Canada) on 8 and 15 July 2013 and 8 and 16 July 2014, respectively. Once emerged, seedlings were fertigated with 150,42 , and $145 \mathrm{mg} \cdot \mathrm{kg}^{-1}$ of $\mathrm{N}$, phosphorus $(\mathrm{P})$, and potassium $(\mathrm{K})$, respectively, on a weekly basis. The fertilizer solution was a mixture of water-soluble fertilizers consisting of $21 \mathrm{~N}-2.2 \mathrm{P}-$ $16.6 \mathrm{~K}$ and $15 \mathrm{~N}-2.2 \mathrm{P}-12.45 \mathrm{~K}-4 \mathrm{Ca}-$ $2 \mathrm{Mg}$ (J.R. Peters, Allentown, PA). During both years, the greenhouse was set to maintain a daytime temperature of $69^{\circ} \mathrm{F}$. Seedlings were hardened off under a shaded structure outside the greenhouse for 1 week before transplanting.

After cover crop soil incorporation, raised beds with black plastic mulch and drip irrigation were formed using a raised bed mulch layer (RB448; Nolt's Produce Supplies, Leola, PA). Each cover crop treatment had four beds. Beds were spaced $6 \mathrm{ft}$ apart (center-to-center) with the bed surface being $2 \mathrm{ft}$ wide on top. Flow rate of installed drip tape was $0.22 \mathrm{gal} /$ $100 \mathrm{ft} / \mathrm{min}$. Lettuce was transplanted using a water wheel transplanter (1600 Series II; Rain-Flo Irrigation, East Earl, PA). Each bed had two rows of lettuce that were 9 inches apart and were staggered. Plants were 12 inches apart within rows. The 

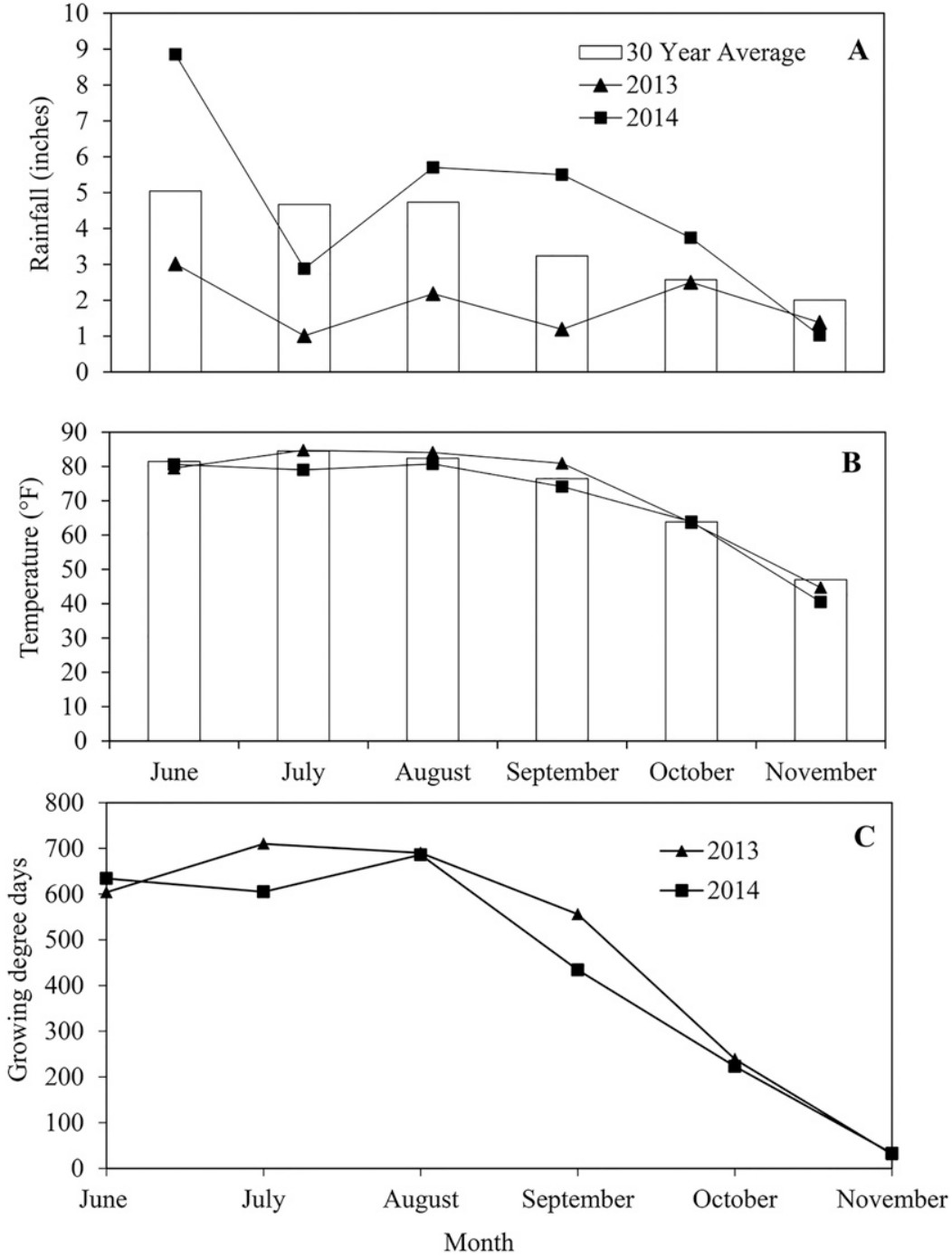

Fig. 1. (A) Accumulated monthly rainfall and (B) average monthly daytime high temperature in 2013, 2014, and the 30-year average at the Horticulture Research Station, Ames, IA. (C) Growing degree days were calculated using $50^{\circ} \mathrm{F}$ base temperature in 2013 and 2014 at the same location; 1 inch $=25.4 \mathrm{~mm},\left({ }^{\circ} \mathrm{F}-32\right) \div 1.8={ }^{\circ} \mathrm{C}$.

subplot treatment with early planting of lettuce was transplanted the same day as cover crop soil incorporation. This occurred on 6 Aug. 2013 and 5 Aug. 2014. Late planting took place $8 \mathrm{~d}$ after the early planting in both years. The lettuce crop in both years was provided a total $\mathrm{N}, \mathrm{P}$, and $\mathrm{K}$ dose of 72,17 , and $168 \mathrm{lb} /$ acre, respectively, using $21 \mathrm{~N}-2.2 \mathrm{P}-16.6 \mathrm{~K}$ fertilizer (J.R. Peters) in two split applications. The soluble fertilizer was injected into the irrigation system using an inline volumetric flow injector (DosmaticPlus; Hydro Systems Co., Cincinatti, OH).

SoIL SAMPLEs. Soil samples were collected at five different times throughout the lettuce growing season: cover crop planting, early lettuce planting, late lettuce planting, first lettuce harvest, and late fall. Sampling dates are
$2=$ transplant has leaf yellowing or lower leaves are drying up, $3=$ transplant has not grown since transplanting, $4=$ transplant has grown up to six or more leaves after transplanting, and $5=$ transplant has grown seven or more leaves after transplanting. A total of 24 plants were sampled within each subplot treatment.

Pest management. Cabbage loopers (Trichoplusia ni) and melon aphids (Aphis gossypii) were primary pests in both years. Table 1 lists products and dates of application of insecticide sprays. In 2013, cabbage loopers were the only pest for which we sprayed. In 2014, two applications were made for cabbage loopers and one for melon aphids.

HaRvest. Cover crop and planting time affected the time required to grow the lettuce from transplant stage to marketable stage. For this reason, treatments were assessed for harvest on a weekly basis to achieve the optimal size so that marketable and nonmarketable portions of lettuce were best represented for data analysis. Lettuce was harvested when $50 \%$ or more of plants at the subplot level were at optimal marketable size. In 2013 , lettuce was harvested from southernpea-early on 20 Sept., from southernpea-late on 27 Sept., and from all other treatments on 2 Oct. In 2014, southernpea-early, buckwheat-early, control-early, and southernpea-late were harvested on 11 Sept. with all other treatment combinations harvested on 24 Sept. Marketable lettuce had a head size of $\approx 20 \mathrm{~cm}$ wide or larger with little to no insect, disease or environmental damage. If the head was less than $20 \mathrm{~cm}$ in diameter and/ or had excessive damage, the head was considered nonmarketable.

Data analysis. Data collected were analyzed using the SAS statistical software (version 9.3; SAS Institute, Cary, NC). PROC GLIMMIX was used and mean separation was done using Fisher's least significant difference at $P \leq$ 0.05 . In the absence of any interaction, data from both years were pooled. Differences between cover crops and cover crop $\times$ planting time interactions were analyzed using the lines statement in PROC GLIMMIX.

\section{Results}

Cover Crop biomass. Aboveground cover crop biomass ranged from $3110 \mathrm{~kg} \cdot \mathrm{ha}^{-1}$ in the southernpea 
treatment to $5173 \mathrm{~kg} \cdot \mathrm{ha}^{-1}$ in the sorghum-sudangrass treatment in 2013 (Table 2). In 2014, cover crop

biomass ranged from $1260 \mathrm{~kg} \cdot \mathrm{ha}^{-1}$ in the southernpea treatment to 2603 $\mathrm{kg} \cdot \mathrm{ha}^{-1}$ in the sorghum-sudangrass
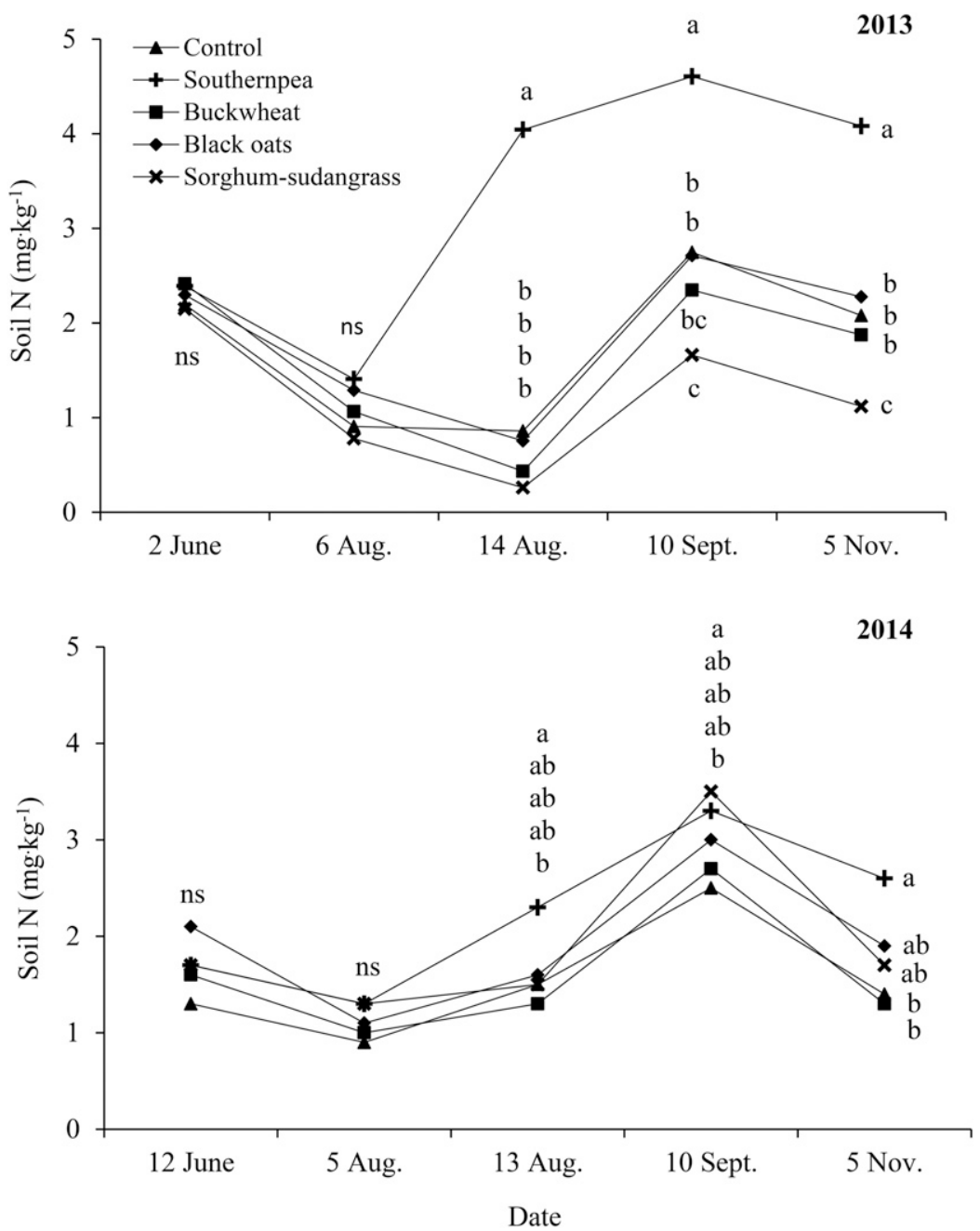

Fig. 2. Soil nitrogen $(\mathrm{N})$ concentration (nitrate + ammonium) as influenced by cover crop over time in year 2013 and 2014 (control = no-cover crop). Mean separation between treatments at each date by least significant difference test at $P \leq 0.05$. Letters match lines from top to bottom (NS = nonsignificant); $1 \mathrm{mg} \cdot \mathrm{kg}^{-1}=1 \mathrm{ppm}$. treatment. Oats and buckwheat produced biomass values in between that of southernpea and sorghum-sudangrass. Control (no-cover crop) plot biomass represents weed biomass collected at the time of cover crop sampling.

WEED BIOMASS. In 2013, weed biomass at the time of cover crop termination was highest in the control treatment for both broadleaves and grasses (Table 3). Buckwheat had the lowest weed biomass for both broadleaves and grasses as compared with all other cover crops with the exception of broadleaves in black oats. Southernpea, black oats, and sorghum-sudangrass were not different from each other in weed suppression. In 2014, weed biomass was highest in the control and southernpea treatments. There was only one exception in the southernpea treatment in the broadleaf category where weed biomass was not different from the buckwheat, black oats, or sorghumsudangrass.

SoIL N. Soil N was measured at specific time periods that included cover crop seeding, early lettuce planting time, late lettuce planting time, first lettuce harvest, and late fall $(40 \mathrm{~d}$ after first lettuce harvest). In 2013, soil $\mathrm{N}$ concentrations were not different at cover crop seeding or early lettuce planting time (Fig. 2A). At the late lettuce planting time, soil $\mathrm{N}$ concentration was highest in the southernpea treatment with all other treatments having no significant differences between each other. At the first lettuce harvest, southernpea treatment maintained the highest

Table 1. Insecticides used in 2013 and 2014 to control cabbage looper and melon aphid on lettuce at the Horticulture Research Station, Ames, IA; including dates of application.

\begin{tabular}{|c|c|c|c|c|}
\hline Date & $\begin{array}{l}\text { Active ingredient } \\
\text { applied }\end{array}$ & $\begin{array}{c}\text { Rate of active } \\
\text { ingredient } \\
(\text { per acre })^{z}\end{array}$ & Commercial formulation applied & $\begin{array}{c}\text { Rate of } \\
\text { formulation } \\
\text { (per acre) }\end{array}$ \\
\hline \multicolumn{5}{|l|}{2013} \\
\hline 6 Sept. & Bacillus thuringiensis & $0.2 \mathrm{lb}$ & Dipel DF ${ }^{\circledR}$ (Valent BioSciences Corp., Libertyville, IL) & $1.0 \mathrm{lb}$ \\
\hline 13 Sept. & $\begin{array}{l}\text { Pyrethrin }+ \\
\text { B. thuringiensis }\end{array}$ & $\begin{array}{l}10.0 \mathrm{fl} \mathrm{oz}+ \\
0.2 \mathrm{lb}\end{array}$ & $\begin{array}{l}\text { PyGanic }^{\circledR}(\text { MGK, Minneapolis, MN })+ \\
\text { Dipel DF }\end{array}$ & $\begin{array}{l}20.0 \mathrm{fl} \mathrm{oz}+ \\
1.0 \mathrm{lb}\end{array}$ \\
\hline 10 Oct. & B. thuringiensis & $0.2 \mathrm{lb}$ & Dipel $\mathrm{DF}^{\circledR}$ & $1.0 \mathrm{lb}$ \\
\hline \multicolumn{5}{|l|}{2014} \\
\hline 23 Sept. & $\begin{array}{l}\text { Acetamiprid }+ \\
\text { Novaluron }\end{array}$ & $\begin{array}{l}2.8 \mathrm{oz}+ \\
1.1 \mathrm{oz}\end{array}$ & $\begin{array}{l}\text { Assail }^{\circledR} \text { (United Phosphorus Inc., King of Prussia, PA) + } \\
\text { Rimon (Chemtura Corp., Middlebury, CT) }\end{array}$ & $\begin{array}{l}4.0 \mathrm{oz}+ \\
12.0 \mathrm{oz}\end{array}$ \\
\hline 29 Sept. & B. thuringiensis & $0.4 \mathrm{lb}$ & Dipel $\mathrm{DF}^{\circledR}$ & $3.7 \mathrm{lb}$ \\
\hline
\end{tabular}

${ }^{\mathrm{z}} \mathrm{l} \mathrm{lb} / \mathrm{acre}=1.1209 \mathrm{~kg} \cdot \mathrm{ha}^{-1}, \mathrm{l} \mathrm{fl} \mathrm{oz} /$ acre $=73.0778 \mathrm{~mL} \cdot \mathrm{ha}^{-1}, \mathrm{l} \mathrm{oz} / \mathrm{acre}=70.0532 \mathrm{~g} \cdot \mathrm{ha}^{-1}$. 
concentration of soil N. Black oats and control treatment were, at this time, higher in soil $\mathrm{N}$ than sorghumsudangrass. At the late fall time, the same trends remained with the addition of buckwheat having higher soil $\mathrm{N}$ than sorghum-sudangrass. In 2014, soil $\mathrm{N}$ concentrations were not different at cover crop seeding and the early lettuce planting time. At the late planting time, southernpea had more soil $\mathrm{N}$ than buckwheat (Fig. 2B). At the first lettuce harvest period, sorghumsudangrass had more soil $\mathrm{N}$ than the control. In the late fall, southernpea had more $\mathrm{N}$ than the control or buckwheat.

SoIL $\mathbf{P}$ AND K. Soil samples for $\mathrm{P}$ and $\mathrm{K}$ were taken the same time as the ones taken for soil $\mathrm{N}$ analysis. Interactions were observed between years, so data were analyzed separately by year. No differences were observed in soil concentrations of $\mathrm{P}$ or $\mathrm{K}$ between any cover crop at any of the sampling dates, thus data are not shown.

Health RATING/score. Interactions were present in both years between cover crop and planting time (Table 4). In 2013, the health score was the highest for southernpea-early

Table 2. Abovegroundcover crop biomass before termination at the Horticulture Research Station, Ames, IA, in 2013 and 2014.

\begin{tabular}{|c|c|c|}
\hline \multirow[b]{2}{*}{ Treatment } & \multicolumn{2}{|c|}{ Biomass $\left(\mathrm{kg} \cdot \mathrm{ha}^{-1}\right)^{\mathrm{z}}$} \\
\hline & 2013 & 2014 \\
\hline $\mathrm{NO}^{-}$ &, 5040 & $2,562 \mathrm{a}$ \\
\hline lack oats & $3,788 \mathrm{bc}$ & $1,987 \mathrm{ab}$ \\
\hline eat & $4,553 \mathrm{ab}$ & $1,540 \mathrm{~b}$ \\
\hline $\begin{array}{l}\text { Sorghum- } \\
\text { sudangrass }\end{array}$ & $5,173 \mathrm{a}$ & $2,603 \mathrm{a}$ \\
\hline$\underline{\text { Southernpea }}$ & $3,110 \mathrm{c}$ & $1,260 \mathrm{~b}$ \\
\hline \multicolumn{3}{|c|}{$\begin{array}{l}{ }^{\mathrm{z}} 1 \mathrm{~kg} \cdot \mathrm{ha}^{-1}=08922 \mathrm{lb} / \mathrm{acre} \\
\mathrm{y} \text { Biomass collected from the no-cover crop plots } \\
\text { represents weed biomass. } \\
{ }^{x} \text { Mean separation within column by the least signifi- } \\
\text { cant difference test at } P \leq 0.05 \text {. Values within each } \\
\text { column sharing the same letter are not different. }\end{array}$} \\
\hline
\end{tabular}

followed by southernpea-late treatment. All other treatments were lower than southernpea-late but not significantly different from each other. In 2014, control-early, buckwheat-early, and southernpea-early had higher health scores than control-late, buckwheatlate, black oats early, black oats-late, sorghum-sudangrass-early, or sorghumsudangrass-late treatments.

Marketable YIELD. In 2013, marketable lettuce weight was not significantly different among any of the treatments or planting times (Table 5). Marketable numbers of heads per acre were higher in the buckwheat-late than in black oats-late, sorghum-sudangrassearly, or sorghum-sudangrass-late treatments. In 2014, the marketable lettuce weight was higher in the control-early, control-late, southernpea-early, and black oats-early than in buckwheatearly, southernpea-late, black oatslate, sorghum-sudangrass-early, and sorghum-sudangrass-late treatments. Marketable numbers of heads were highest in southernpea-early compared with all other treatments with the exception of control-early, control-late, and black oats-early treatments.

Nonmarketable Weight. Nonmarketable lettuce weight was higher in the southernpea-late and black oats-late than the buckwheat-late or southernpea-early treatment in 2013 (Table 5). In 2014, nonmarketable lettuce weight was not significant among any of the cover crop or planting time treatments.

\section{Discussion}

There is certainly a place for cover crops in vegetable cropping systems; however, the challenge is to identify approaches and planting systems that facilitate cover crop integration without compromising vegetable yield and quality. Cover crops tested in this study have different growth habits and morphology which significantly influence/dictate benefits they can provide. In addition to providing benefits to the environment, cover crops can also detrimentally affect the succeeding vegetable crop.

One of the most sought after attribute of a cover crop is biomass generation. This biomass, when turned into the soil, increases soil organic matter, improves soil physical and chemical properties, and enhances soil biology (Nair and Ngouajio, 2012). Cover crop biomass generation is largely dependent on planting season-specific cover crops, planting method, soil moisture, and prevailing weather conditions. In this study, cover crop biomass generated in 2013 was higher than in 2014 . Rainfall amount in June 2014 was almost three times that of June 2013. Higher rainfall led to higher nutrient leaching thereby reducing cover crop growth. In 2013, sorghum-sudangrass produced the highest amount of biomass. Sorghum-sudangrass is a tall, fast growing, heat-loving summer annual grass cover crop that can produce ample biomass, usually between 4000 to $5000 \mathrm{lb} /$ acre (Clark, 2007). Although in this study we did not mow sorghum-sudangrass, mowing when stalks reach 2 to $4 \mathrm{ft}$ can increase root biomass, which helps with breaking soil compaction. In this study, buckwheat also stood out as a suitable cover crop that can fit in the narrow summer fallow window. This cover crop provides a quick soil cover, suppresses weeds, and also has an additional advantage of providing nectar for pollinators and beneficial insects (Nair and Kruse, 2015).

In addition to biomass, cover crops suppress weeds, both while the cover crop is actively growing and often after they are incorporated in the soil. In this study, cover crops reduced weeds in both years. This is similar to findings of Creamer and Baldwin (2000) and Wang et al.

Table 3. Weed biomass within cover crop treatments at the Horticulture Research Station, Ames, IA, in 2013 and 2014.

\begin{tabular}{|c|c|c|c|c|c|c|}
\hline \multirow[b]{2}{*}{ Treatment } & \multicolumn{3}{|c|}{2013 Weed biomass $\left(\mathrm{kg} \cdot \mathrm{ha}^{-1}\right)^{\mathrm{z}}$} & \multicolumn{3}{|c|}{2014 Weed biomass $\left(\mathrm{kg} \cdot \mathrm{ha}^{-1}\right)$} \\
\hline & Broadleaf & Grass & Total $^{y}$ & Broadleaf & Grass & Total \\
\hline No-cover crop & $1,290 a^{x}$ & $2,000 \mathrm{a}$ & $3,300 \mathrm{a}$ & $1,100 \mathrm{a}$ & $1,310 \mathrm{a}$ & $2,410 \mathrm{a}$ \\
\hline Buckwheat & $60 \mathrm{c}$ & $200 \mathrm{c}$ & $260 \mathrm{c}$ & $170 \mathrm{~b}$ & $610 \mathrm{~b}$ & $790 \mathrm{~b}$ \\
\hline Sorghum-sudangrass & $620 \mathrm{~b}$ & $980 \mathrm{~b}$ & $1,600 \mathrm{~b}$ & $350 \mathrm{~b}$ & $330 \mathrm{~b}$ & $680 \mathrm{~b}$ \\
\hline Southernpea & $640 \mathrm{~b}$ & $1,010 \mathrm{~b}$ & $1,640 \mathrm{~b}$ & $590 \mathrm{ab}$ & $1,230 \mathrm{a}$ & $1,810 \mathrm{a}$ \\
\hline
\end{tabular}

${ }^{\mathrm{z}} \mathrm{l} \mathrm{kg} \cdot \mathrm{ha}^{-1}=0.8922 \mathrm{lb} / \mathrm{acre}$

yTotal represents the combined value of broadleaf and grass weed biomass within each cover crop treatment.

${ }^{x}$ Mean separation within column by the least significant difference test at $P \leq 0.05$. Values within each column sharing the same letter are not different. 
(2008b), who also observed weed suppression through the use of cover crops. The study by Creamer and
Baldwin (2000) showed cover crops grown in midsummer similar to the current study. Cover crops studied

Table 4. Lettuce transplant health score as affected by cover crop and planting time in 2013 and 2014 at the Horticulture Research Station, Ames, IA.

\begin{tabular}{|c|c|c|}
\hline \multirow[b]{2}{*}{ Cover crop/planting time } & \multicolumn{2}{|c|}{ Health score $(1-5 \text { scale })^{\mathrm{z}}$} \\
\hline & 2013 & 2014 \\
\hline \multicolumn{3}{|l|}{ No-cover crop } \\
\hline Early & $2.9 c^{y}$ & $4.0 \mathrm{a}$ \\
\hline Late & $3.0 \mathrm{c}$ & $3.2 \mathrm{dc}$ \\
\hline \multicolumn{3}{|l|}{ Black oats } \\
\hline Early & $2.9 \mathrm{c}$ & $3.5 \mathrm{bc}$ \\
\hline Late & $3.0 \mathrm{c}$ & $3.0 \mathrm{~d}$ \\
\hline \multicolumn{3}{|l|}{ Buckwheat } \\
\hline Early & $2.9 \mathrm{c}$ & $3.9 \mathrm{a}$ \\
\hline Late & $3.0 \mathrm{c}$ & $3.0 \mathrm{~d}$ \\
\hline \multicolumn{3}{|l|}{ Sorghum-sudangrass } \\
\hline Early & $3.0 \mathrm{c}$ & $3.1 \mathrm{~d}$ \\
\hline Late & $3.0 \mathrm{c}$ & $2.9 \mathrm{~d}$ \\
\hline \multicolumn{3}{|l|}{ Southernpea } \\
\hline Early & $4.0 \mathrm{a}$ & $4.0 \mathrm{a}$ \\
\hline Late & $3.4 \mathrm{~b}$ & $3.7 \mathrm{ab}$ \\
\hline \multicolumn{3}{|l|}{ Significance } \\
\hline Cover crop $(\mathrm{C})$ & $* * *$ & $* * *$ \\
\hline Planting time $(\mathrm{P})$ & * & $* * *$ \\
\hline $\mathrm{C} \times \mathrm{P}$ & $* * *$ & * \\
\hline
\end{tabular}

${ }^{2}$ Health score rating of transplants assigned on 20 Aug. 2013 and 15 Aug. 2014 using following 5 -point scale: 1 = dead; 2 = leaf yellowing or lower leaves were drying up; $3=$ no growth since transplanting; $4=$ transplant has three to six new leaves; $5=$ transplant has seven or more new leaves.

yean separation between treatments within columns by least significant difference test at $P \leq 0.05$. Values within each column sharing the same letter are not different.

${ }^{*},{ }^{* *},{ }^{* *}$ Significant at $P \leq 0.05,0.01$, or 0.001 , respectively, based on least significant difference test.

included buckwheat, southernpea, and sorghum-sudangrass, all of which suppressed weed growth compared with the control. There was only one cover crop in 2014, southernpea, which did not reduce weeds when compared with the control in the current study. In 2013, when compared with the control plot, buckwheat reduced broadleaf, grass, and total weed (broadleaf + grasses) biomass by $95 \%, 90 \%$, and $92 \%$, respectively (Table 3 ), which is quite significant. Although the level of weed biomass suppression is subjective, $90 \%$ to $95 \%$ weed suppression without letting existing weeds go to seed makes a good case for cover crops as a weed management tool. In 2013, black oats, southernpea, and sorghumsudangrass reduced total weed biomass by only $64 \%, 50 \%$, and $52 \%$, respectively. Sorghum-sudangrass produced higher biomass but that did not translate to total weed biomass suppression. In 2014, the degree of total weed suppression by cover crops was reduced and ranged from $25 \%$ to $67 \%$; however, buckwheat still provided $85 \%$ weed suppression of broadleaf weeds, when compared with the control. The reduction in the degree of weed suppression in 2014 could

Table 5. Cover crop and planting time effect on marketable and nonmarketable lettuce head weight and number at the Horticulture Research Station, Ames, IA, in 2013 and 2014.

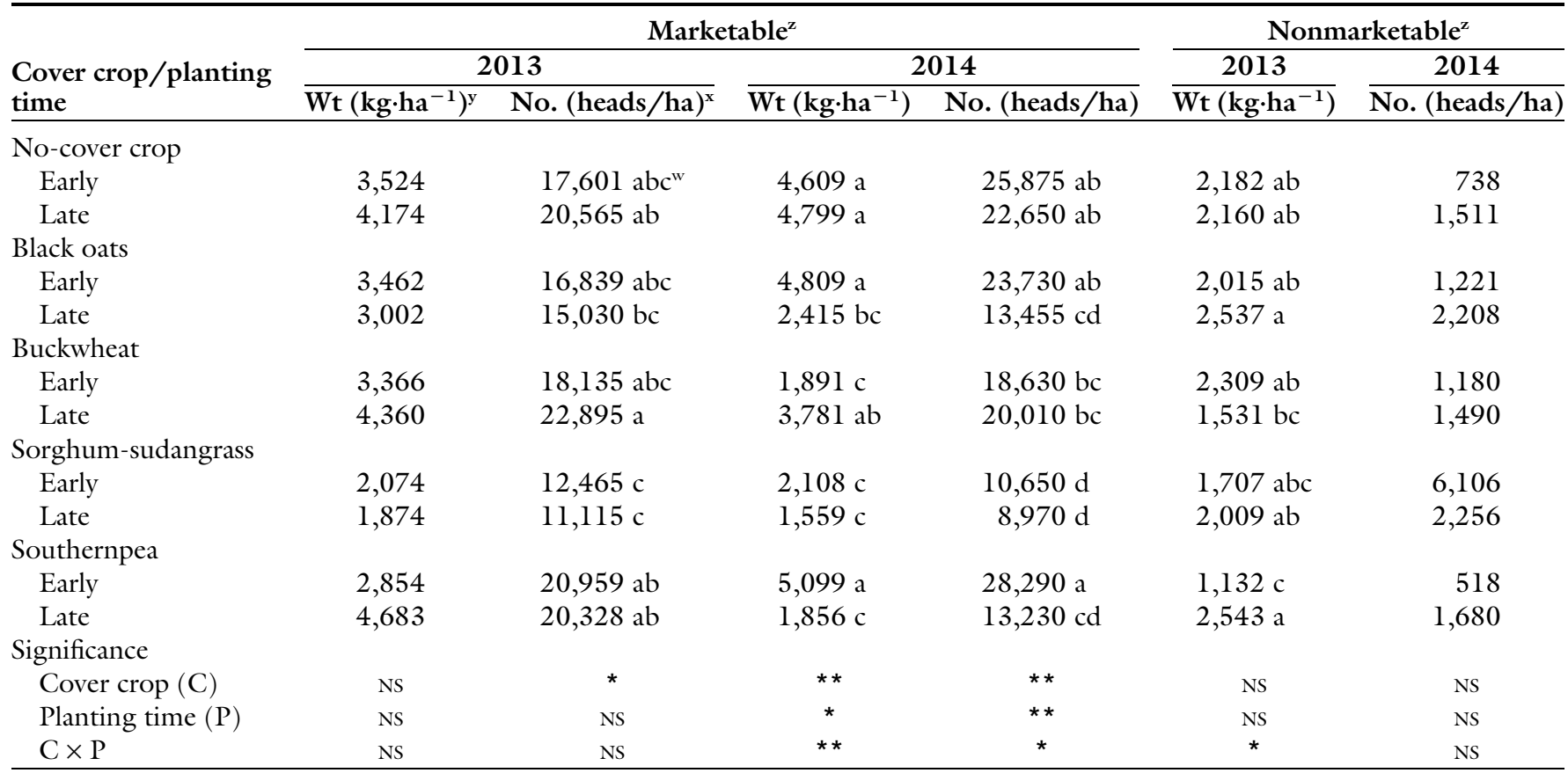

${ }^{\mathrm{z}}$ Marketable lettuce has a head $\approx 20 \mathrm{~cm}$ (7.9 inches) wide with no cuts, bruises, lesions, or pest damage. Nonmarketable lettuce has a head size less than $20 \mathrm{~cm}$ wide and/or with cuts, bruises, lesions, or pest damage.

${ }^{y}$ Weight was measured with the lower wrapper leaves removed; $1 \mathrm{~kg} \cdot \mathrm{ha}^{-1}=0.8922 \mathrm{lb} / \mathrm{acre}$

${ }^{x}$ Count per hectare is the number of marketable heads that make up the marketable vield; 1 head $/ \mathrm{ha}=0.4047 \mathrm{head} / \mathrm{acre}$.

${ }^{\text {w}}$ Mean separation between treatments within columns was done by least significant difference test at $P \leq 0.05$. Values within each column sharing the same letter are not different. NS, ${ }^{*},{ }^{* *},{ }^{* *}$ Nonsignificant or significant at $P \leq 0.05,0.01$, or 0.001 , respectively, based on least significant difference test. 
be due to reduced biomass production. Southernpea provided only $46 \%$ and $6 \%$ reduction of broadleaf and grass weeds, respectively. Growers should not expect a higher degree of weed suppression from southernpea, but the $\mathrm{N}$ fixing capability of southernpea is an additional benefit. Southernpea has performed well in southern and mid-Atlantic United States and more studies are needed in the midwestern and north-central United States. With the wide diversity of cover crops available, a good cover crop stand can be used as a valuable and sustainable weed management tool during a short fallow period in a growing season; however, the degree of weed suppression will differ based on cover crop type, climate, and cultural practices.

Among the cover crops in 2013, southernpea significantly increased soil $\mathrm{N}$, whereas in 2014 , the increase was not significant. This could be attributed to the increased precipitation in 2014 (Fig. 1A) and reduced southernpea biomass. The additional rainfall in 2014 could have led to enhanced leaching of soil $\mathrm{N}$. The increased amount of $\mathrm{N}$ from southernpea in both years can be attributed to southernpeas' ability to fix $\mathrm{N}$ as well as its low carbon $(\mathrm{C}): \mathrm{N}$ ratio (Creamer and Baldwin, 2000). When comparing cover crops in this study, no one crop provides a clear advantage in lettuce production.

Cover crops, depending on how they are deployed in the production system, sometimes have negative effects on cash crops. Negative effects include interference with cash crop planting, $\mathrm{N}$ immobilization, and/or allelopathic effects. In this study, overall, sorghum-sudangrass did not have any significant beneficial effect on the lettuce crop. Lettuce from sorghumsudangrass plots consistently trended to have lower yield and smaller head diameter relative to all other treatments. Marketable lettuce head weight and number in the sorghum-sudangrass treatment, in 2014, were significantly lower than the control treatment. Wang et al. (2008a) saw the same trend where sorghum-sudangrass rarely offered a benefit over the control but often detrimentally affected the lettuce crop. This also agrees with Finney et al. (2009) who also observed detrimental effects of sorghum-sudangrass on a following cabbage crop. Results from our study lead us to conclude that sorghum-sudangrass detrimentally affects the succeeding lettuce crop and growers should be careful when using sorghum-sudangrass. There could be two possible explanations for the negative effect of sorghum sudangrass on lettuce. First, there is the possibility that sorghum-sudangrass, due to the high $\mathrm{C}: \mathrm{N}$ ratio in its biomass (Creamer and Baldwin, 2000), could have tied up soil $\mathrm{N}$ rendering it unavailable to the lettuce crop (Kuo and Sainju, 1998). Second, there are studies that have attributed vegetable yield loss to allelochemical properties from sorghumsudangrass (Finney et al., 2009). The soil $\mathrm{N}$ data in our study show sufficient $\mathrm{N}$ in the soil. This leads us to the conclusion that allelopathy could have played a role in detrimentally affecting lettuce yield and quality.

When examining the harvest dates of lettuce across both years, the southernpea-early and southernpealate treatments were among the first to be harvested, with the exception of buckwheat-early and controlearly treatments in 2014. This demonstrates the positive influence of southernpea cover crop on lettuce. Lettuce plants in the southernpea treatment spent less time in the field being exposed to weather, insects, or pathogens that could decrease marketable yield. Additional soil N added by the southernpea cover crop could have contributed to faster growth and overall superior quality. The high amount of soil nitrate and ammonium found in 2013 in the southernpea treatment would explain why southernpea-early and southernpea-late were the first treatments harvested. Similarly, in 2014, the southernpea treatment tended to have higher soil nitrate and ammonium when compared with other treatments at the late lettuce planting time and late fall. Nitrogen is one of the key nutrients that affects plant growth and its increased availability can enhance the speed of plant growth (Walker et al., 2001).

In this study, there was no clear pattern indicating that planting immediately after cover crop incorporation negatively affects plant growth. Earlier planting of fall crops can affect the time to harvest. In 2014, lettuce in the buckwheat-early and control-early treatments reached optimal size $5 \mathrm{~d}$ ahead of the buckwheat-late or control-late treatments. The extra $8 \mathrm{~d}$ of growth, due to early planting, before daylength, degree days, and light quality diminished in the fall, benefited the crop (Fig. IB and C). This strengthens the argument that in northern climatic regions, like Iowa and the midwestern United States, planting immediately after cover crop soil incorporation could result in a better quality lettuce crop. This disagrees with past research by Ackroyd and Ngouajio (2011), who suggest a planting time of $8 \mathrm{~d}$ or longer after cover crop soil incorporation. That study examined the effect of oilseed radish (Raphanus sativus var. oleifera), oriental mustard (Brassica juncea), and yellow mustard (Sinapis alba) cover crops, which are known to produce isothiocyanates that act as biofumigants. Additionally, the study focused on direct seeding of muskmelon (Cucumis melo Group reticulatus) rather than on transplants, as in the case of our study.

In conclusion, this study observed specific advantages with certain cover crops and planting time of the cash crop after soil incorporation of cover crops. All cover crops (black oats, buckwheat, and sorghumsudangrass) except southernpea reduced weed biomass in both years when compared with the control. Southernpea treatment also reduced weed biomass, but only in 2013. Even though southernpea did not provide a higher degree of weed suppression it could benefit the succeeding crop by adding soil $\mathrm{N}$ through $\mathrm{N}$ fixation. Lettuce planted after southernpea cover crop tends to be higher in yield and quality. Sorghum-sudangrass cover crop negatively influenced lettuce yield and quality. For growers deciding when to plant after cover crop termination, it appears that planting early would yield a higher quality lettuce crop. More studies are needed to ascertain optimal planting time after soil incorporation of sorghumsudangrass. A key point to consider while integrating cover crops is that the value of cover crop is not just in enhancing successive vegetable crop yields, but in other soil and environmental benefits it imparts to the entire production system.

\section{Literature cited}

Ackroyd, V.J. and M. Ngouajio. 2011. Brassicaceae cover crops affect seed germination and seedling establishment in 
cucurbit crops. HortTechnology 21:525532.

Bugg, R. and J. Dutcher. 1989. Warmseason cover crops for pecan orchards: Horticultural and entomological implications. Biol. Agr. Hort. 6:123-148.

Buyer, J.S., J.R. Teasdale, D.P. Roberts, I.A. Zasada, and J.E. Maul. 2010. Factors affecting soil microbial community structure in tomato cropping systems. Soil Biol. Biochem. 42:831-841.

Chatham, L.A., K.W. Bradley, G.R. Kruger, J.R. Martin, M.D.K. Owen, D.E. Peterson, J. Mithila, and P.J. Tranel. 2015. A multistate study of the association between glyphosate resistance and EPSPS gene amplification in waterhemp (Amaranthus tuberculatus). Weed Sci. 63:569-577.

Clark, A. 2007. Managing cover crops profitably. 3rd ed. Sustainable Agr. Network, Beltsville, MD.

Corak, S., T. Kaspar, and R. Horton. 1991. Fall-planted spring oats: A low-risk cover crop to reduce erosion following soybeans. Soil Water Conservation Soc., Ankeny, IA.

Creamer, N.G. and K.R. Baldwin. 2000. An evaluation of summer cover crops for use in vegetable production systems in North Carolina. HortScience 35:600-603.

De Baets, S., J. Poesen, J. Meersmans, and L. Serlet. 2011. Cover crops and their erosion-reducing effects during concentrated flow erosion. Catena 85:237-244.

Ding, G., X. Liu, S. Herbert, J. Novak, D. Amarasiriwardena, and B. Xing. 2006.
Effect of cover crop management on soil organic matter. Geoderma 130:229-239.

Finney, D.M., N.G. Creamer, J.R. Schultheis, M.G. Wagger, and C. Brownie. 2009. Sorghum sudangrass as a summer cover and hay crop for organic fall cabbage production. Renew. Agr. Food Syst. 24: 225-233.

Iowa State University. 2015. Iowa environmental mesonet. 4 Sept. 2015. <http:// mesonet.agron.iastate.edu>.

Kumar, V., D.C. Brainard, and R.R. Bellinder. 2009. Effects of spring-sown cover crops on establishment and growth of hairy galinsoga (Galinsoga ciliata) and four vegetable crops. HortScience 44:730-736.

Kuo, S. and U.M. Sainju. 1998. Nitrogen mineralization and availability of mixed leguminous and non-leguminous cover crop residues in soil. Biol. Fert. Soils 26: 346-353.

Mukherjee, A. and R. Lal. 2015. Shortterm effects of cover cropping on the quality of a Typic Argiaquolls in central Ohio. Catena 131:125-129.

Nair, A. and M. Ngouajio. 2012. Soil microbial biomass, functional microbial diversity, and nematode community structure as affected by cover crops and compost in an organic vegetable production system. Appl. Soil Ecol. 58:45-55.

Nair, A. and R. Kruse. 2015. Short duration cover crops for vegetable production systems. Iowa State Univ. Ext. HORT3041.

Reicosky, D.C., W.D. Kemper, G.W. Langdale, C.L. Douglas, and P.E.
Rasmussen. 1995. Soil organic matter changes resulting from tillage and biomass production. J. Soil Water Conserv. 50:253-261.

Rueda-Ayala, V., O. Jaeck, and R. Gerhards. 2015. Investigation of biochemical and competitive effects of cover crops on crops and weeds. Crop Prot. 71:79-87.

Sainju, U.M., B.P. Singh, and W.F. Whitehead. 2002. Long-term effects of tillage, cover crops, and nitrogen fertilization on organic carbon and nitrogen concentrations in sandy loam soils in Georgia, USA. Soil Tillage Res. 63:167-179.

Teasdale, J.R. 1996. Contribution of cover crops to weed management in sustainable agricultural systems. J. Prod. Agr. 9:475-479.

Walker, R.L., I.G. Burns, and J. Moorby. 2001. Responses of plant growth rate to nitrogen supply: A comparison of relative addition and $\mathrm{N}$ interruption treatments. J. Expt. Bot. 52:309-317.

Wang, G., M. Ngouajio, M.E. McGiffen, and C.M. Hutchinson. 2008a. Summer cover crop and in-season management system affect growth and yield of lettuce and cantaloupe. HortScience 43:13981403.

Wang, G., M. Ngouajio, and D.D. Warncke. 2008b. Nutrient cycling, weed suppression, and onion yield following brassica and sorghum sudangrass cover crops. Hort Technology 18:68-74. 